\title{
AUCTIONEERS' LIABILITY FOR CONVERSION UNDER THE PACKERS AND STOCKYARDS ACT*
}

AN agent who, in the ordinary course of business, sells goods his principal obtained through fraud or theft is liable in conversion to the rightful owner. Good faith and ignorance of the true owner's title do not relieve the agent of liability. ${ }^{1}$ Nor can he raise the defense of merely acting on his principal's behalf; he is considered a joint tort-feasor in the conversion. ${ }^{2}$ Occasionally, courts and legislatures have abrogated this common-law rule for agents who can be deemed conduits or public utilities. ${ }^{3}$ Yet regulatory legislation alone

*United States v. Matthews, 244 F.2d 626 (9th Cir. 1957), reversing 139 F. Supp. 683 (N.D. Cal. 1956).

1. Kearney v. Clutton, 101 Mich. 106, 59 N.W. 419 (1894) ; Spraights v. Hawley, 39 N.Y. 441 (1868) ; First Nat'l Bank v. Siman, 65 S.D. 514, 275 N.W. 347 (1937). 1 HARPER \& JaMres, Torts $§ 2.19$ (1956); see 14 U. Chi. L. Rev. 713 (1947) ; 2 Mechem, Agency $\$ 2345$ (1914) (auctioneers). Contra, Frizzell v. Rundle \& Co., 88 Tenn. 396, 12 S.W. 918 (1890). See also 1 Restatement, Torts $\S 233$, comment $b$ (1934), which finds an innocent agent liable for conversion only where his exercise of dominion involves negotiation of the transaction purporting to transfer a proprietary interest in the chattel as well as consummation of the transaction by a transfer of possession.

Hoffman v. Carow, 22 Wend. 285, 318 (N.Y. 1839), formulated the rule of strict liability: "[E]very man [must] look to the character of those with whom he deals, and who are responsible for the title of property in the articles bought and sold. If he does not do this, he must take the consequent risk. The same considerations of public policy apply to him who sells as the agent of another, as to him who buys; both of them are to look to the character of the person with whom they deal. If in this way they are negligent, or have been deceived, they must take the consequences whenever their rights come into conflict with those of any innocent sufferer by the act of the same guilty third party."

2. Such a defense assumes that the agency relationship may absolve the agent. But no common-law principle exists which exempts one person from the consequences of his acts because of the command of another. SEAvey, Studies IN AGENCY 2 (1949); Note, 4 U. PItr. L. REv. 46 (1937). The principal's fraud is not imputed to the agent. The agent of a tortious principal is liable because he participates in the commission of the tort. Levy Bros. v. Karp, 124 Misc. 901,209 N.Y. Supp. 720 (Sup. Ct. 1924); see Birmingham v. Rice Bros., 238 Iowa 410, 413, 26 N.W.2d 39, 41, cert. denied, 332 U.S. 768 (1947); 2 Restatement, Agency $\$ 349$ (1933). See also 1 Harper \& Janies, Torts $\$ 2.19$ (1956), suggesting that, outside the negotiable instruments field, the defense of acting for another is properly denied only in cases of dispossession, destruction and detention of a chattel at the direction of the principal, or when the agent himself negotiates a sale or purchase on behalf of his principal and delivers or receives the goods pursuant thereto; Leuthold $v$. Fairchild, 35 Minn. 99, 27 N.W. 503 (1886).

3. The "conduit" exception to the prevailing rule was first set forth in a dissent in Hoffman v. Carow, 22 Wend. 285, 307 (N.Y. 1839) : "The only ground upon which a party should be held liable, is that he has the property or its value in his possession, or has with knowledge or under notice, illegally disposed of it; and not by reason of having been the mere conduit for its transmission from one to another...." This line of reasoning has been specifically followed in Nanson v. Jacob, 93 Mo. 331, 339, 6 S.W. 246, 249 (1887) ("a mere bailee ... is guilty of no conversion, though he receive property from one not rightfully entitled to possession, and, acting as a mere conduit, deliver it in pursuance of the bail- 
does not confer immunity. ${ }^{4}$ Thus, when Congress placed livestock commission agents under the Packers and Stockyards Act without granting explicit immunity, the scope of liability remained undefined.5

ment") ; Cresswell v. Leftridge, 194 S.W.2d 48 (Mo. Ct. App. 1946) (citing Nanson v. Jacob, supra); Gruntal v. United States Fidelity and Guarantee Co., 254 N.Y. 468, 474, 173 N.E. 682, 684 (1930) (stockbroker "is a mere conduit between the seller and the purchaser"). The public utility exception, invoked in similar situations, is equally well developed. See Blackwell v. Laird, 236 Mo. App. 1217, 163 S.W.2d 91 (1942) (livestock commission agent a public utility and not liable) ; Sullivan Co. v. Wells, 89 F. Supp. 317 (D. Neb. 1950) (same, alternative ground) ; Shellnut v. Central of Ga. Ry., $131 \mathrm{Ga} .404,62$ S.E. 294 (1908) (same, common carrier). See also Note, 33 Texas L. REv. 534 (1955).

Although couched in different language, the exceptions are not always distinguishable. See Abernathy v. Wheeler, $92 \mathrm{Ky} .320,17 \mathrm{~S} . \mathrm{W} .858$ (1891) (warehouseman a public intermediary and hence not liable), which seems to rely on both. A fundamental notion underlying the conduit exception stresses the absence of an agent's property interest in goods over which dominion is asserted. An auctioneer, for instance, may be thought not to claim chattels as his own since he assumes no possessory rights to them. Green v. Crye, 158 Tenn. 109, 11 S.W.2d 869 (1928). However, the conduit exception is particularly applicable to common carriers, which also enjoy immunity from conversion as public utilities. And to put factors, commission agents and auctioneers under the rubric of conduit, the technical objection that such agents assist in passing title, while carriers do not, must be circumvented. See 32 Minn. L. Rev. 86 (1947) (commission agents).

The public utility exception, which derives from the requirement that businesses affected with a public use serve all without discrimination, can be used in nonconduit cases. A private business, while liable for unintentional conversion, can exercise choice by refusing to deal with certain customers. A public utility exchanges this privilege of choice for the judicial compensation of escaping liability for conversion. See 1. Wyaran, Public Service Corporations $\$ \S 331,604$ (1911). See also Farmers Livestock Comm'n Co. v. United States, 54 F.2d 375 (E.D. Ill. 1931) (business affected with public use must serve all without discrimination).

For an example of legislatively granted immunity, see Mont. Rev. Codes ANN. $\$ 52-$ 319 (Supp. 1957) : "No livestock market to which livestock is shipped shall be held liable to any mortgagee for the proceeds of livestock sold through such livestock market by the mortgagor...."

4. Immunity is especially uncertain if prior case law placed liability on the intermediate agent. Subsequent legislation may denominate the agent a public utility and regulate him accordingly. Any resulting ambiguity is usually decided in favor of liability, since protection of the owner's title and right is generally a more favored principle than limited liability of public utilities. See Citizens State Bank v. Farmers Union Livestock Cooperative Co., 165 Kan. 96, 193 P.2d 636 (1948) ; cf. John Clay \& Co. Livestock Comm'n v. Clements, 214 F.2d 803 (5th Cir. 1954).

5. 42 STAT. 159 (1921), as amended, 7 U.S.C. $\$ \$ 181-231$ (1952). Although stockyard agencies are not designated public utilities in the statute, strict regulation coupled with a duty to deal with all customers on a nondiscriminatory basis has been interpreted as making them such. Stafford v. Wallace, 258 U.S. 495, 516 (1922); see 31 MarQ. L. Rev. 103-04 (1947).

Some courts have construed the statute not to relieve market agencies, despite their public utility status, from tort liability for wrongful conversion to avoid abrogating "legal rights subsisting in the general public under state laws." Birmingham v. Rice Bros., 238 Iowa 410, 418, 26 N.W.2d 39, 43, cert. denied, 332 U.S. 768 (1947); see Sig Ellingson v. De Vries, 199 F.2d 677 (8th Cir. 1952), cert. denied, 344 U.S. 934 (1953) ; Mason City Production Credit Ass'n v. Sig Ellingson \& Co., 205 Minn. 537, 286 N.W. 713, cert. dented, 
Recently, in United States $v$. Matthews, ${ }^{6}$ the Ninth Circuit confirmed the liability of livestock auctioneers doing business under the act. ${ }^{7}$ In Matthews, the principal executed a chattel mortgage in favor of the Farmers' Home Administration, a United States government agency. ${ }^{8}$ Duly recorded at execution, the mortgage covered specific livestock, among other farm chattels, and contained the usual provision for immediate possession upon default. ${ }^{3}$ Defaulting shortly after execution, mortgagor periodically removed certain of the livestock from the county of recordation to an adjoining county where he fraudulently consigned them to an auctioneer operating under the act. ${ }^{10}$ After obtaining the mortgagor's written warranty of clear title, the auctioneer sold the livestock at auction and paid the mortgagor the proceeds less commission. ${ }^{11}$ The government brought suit in a federal court against the auctioneer almost three years after default. ${ }^{12}$ Federal law obtained because the suit was based on government paper. ${ }^{13}$

308 U.S. 599 (1939), Walker v. Caviness, 256 S.W.2d 880 (Tex. Civ. App. 1953) ; FrkE, Digest Decisions Under the Packers and Stockyards Act 29 (1942) (citing Mason City Production Credit Ass'n v. Sig Ellingson \& Co., supra) : "Courts should be slow to conclude that the Act was designed to supersede local law respecting the force and effect of chattel mortgage security received at public stockyards."

Other courts, relying on the agent's public utility status under the Packers and Stackyards Act, have exonerated commission agents for liability in conversion. United States v. Kramel, 234 F.2d 577 (8th Cir. 1956); Sullivan v. Wells, 89 F. Supp. 317 (D. Neb. 1950) ; Blackwell v. Laird, 236 Mo. App. 1217, 163 S.W.2d 91. (1942). The Supreme Court has neither settled federal law in point nor determined whether the act required a change in state law to protect interstate commerce.

6. 244 F.2d 626 (9th Cir. 1957), reversing 139 F. Supp. 683 (N.D. Cal. 1956).

7. By far the majority of recent cases involve livestock commission agents. See, e.g., Mason City Production Credit Ass'n v. Sig Ellingson \& Co., 205 Minn. 537, 286 N.W. 713, cert. denied, 308 U.S. 599 (1939) (stockyard agents held liable for selling cattle subject to a chattel mortgage); John Clay \& Co. Livestock Comm'n v. Clements, 214 F.2d 803 (5th Cir. 1954) (resale of livestock for fraudulent purchaser); Citizens State Bank v. Farmers Union Livestock Cooperative Co., $165 \mathrm{Kan} .96,193$ P.2d 636 (1.948) (sale of livestock subject to a chattel mortgage); $c f$. Morin v. Hood, 96 N.H. 485,79 A.2d 4 (1951) (wrongful sale of fixtures subject to a chattel mortgage).

8. 244 F.2d at 627 .

9. Id. at $627-28$.

10. United States v. Matthews, 139 F. Supp. 683, 684 (N.D. Cal. 1956).

11. 244 F.2d at 628.

12. Ibid.

13. Had federal jurisdiction arisen on diversity grounds, state law would have prevailed. Erie R.R. v. Tompkins, 304 U.S. 64 (1938). Relevant California law imiposes liability on an innocent auctioneer when his principal does not have good title to the chattels sold. See Swim v. Wilson, 90 Cal. 126, 27 Pac. 33 (1891) (innocent stockbroker liable to true owner for selling shares stolen by third person); Lusitanian-American Development Co. v. Seaboard Dairy Credit Corp., 1 Cal. 2d 121, 34 P.2d 139 (1934) (auctioneer liable in conversion to conditional vendor). Neither the district court nor the circuit court in Matthews, however, resorted to state law; instead, they relied on Clearfield Trust $C_{0}$. v. United States, 318 U.S. 363 (1943). The Clearfield doctrine prefers federal to state law if commercial paper issued by the United States is the basis for a suit. See contra, United States v. Kramel, 234 F.2d 577 (8th Cir. 1956) (state law prevails where government 
The court treated the case as a variation on the common-law triangle of principal-mortgagor, agent-auctioneer, and rightful owner out of possession -mortgagee. ${ }^{14}$ Since the auctioneer stood in the shoes of his principal, it reasoned, he could not avoid liability despite his innocence. ${ }^{15}$ Nor could he invoke that provision of the Packers and Stockyards Act compelling stockyard agencies to furnish upon reasonable request nondiscriminatory services to all sellers, handlers and purchasers. ${ }^{16}$ Presumably, an auctioneer's refusal to serve an apparent owner without some proof of identity and title would not amount to unreasonable discrimination. ${ }^{17}$

sues in conversion on chattel mortgage held by FHA). Enabled to rely on federal common law, the district court followed Drovers' Cattle Loan \& Inv. Co. v. Rice, 10 F.2d 510 (N.D. Iowa 1926), a diversity case decided before Erie and hence governed by the rule of Swift v. Tyson, 41 U.S. (16 Pet.) 1 (1842), which did not compel federal courts to follow state law. The Rice court made no mention of the Packers and Stockyards Act but held that bona fide commission merchants were not subject to constructive notice of a chattel mortgage on fraudulently obtained livestock.

14. Of the remedies available to the government, indemnification from the auctioneer is probably the most certain. The auctioneer is usually reachable and solvent, while the ultimate purchaser has either vanished or looks to a factors' act for protection. Largely confined to sales through commission merchants in agricultural produce markets, factors' acts may give an innocent purchaser good title against the true owner. Gilmore, The Commercial Doctrine of Good Faith Purchase, 63 YALE L.J. 1057, 1058 (1954) ; Gilmore, On the Difficulties of Codifying Commercial Law, 57 YALE L.J. 1341, 1346 (1948). See also 2 WILliston, SAles $\$ 320$ (1948), for a collection of state factors' acts. Thus, the government may actually be reduced to choosing between the auctioneer and the fraudulent mortgagor, a dilemma easily resolved against the auctioneer. An owner whose goods have been stolen faces similar problems. For a comparison in a negotiable instrument context, see Note, 66 YALE L.J. 1107, 1108-09 (1957).

15. "The factor, even thongh innocent . . . is liable if he assists in . . . conversion because he stands in the shoes of his principal." 244 F.2d at 629, citing Birmingham v. Rice Bros., 238 Iowa 410, 414-15, 26 N.W.2d 39, 42, cert. denied, 332 U.S. 768 (1947). But the maxim, "like principal, like agent," is inappropriately applied to the present situation. See note 2 supra and accompanying text.

16. 42 Stax. 164 (1921), as amended, 7 U.S.C. $\$ 205$ (1952), provides: "It shall be the duty of every stockyard owner and market agency to furnish upon reasonable request, without discrimination, reasonable stockyard services ...." Courts have interpreted the requirements of this section as substantially in accord with the common-law rule applicable to public utilities in general. See note 5 supra. See also Farmers Livestock Comm'n Co. v. United States, 54 F.2d 375 (E.D. Ill. 1931) (individual refusal to buy from or sell to a customer, as well as concerted boycott, a discriminatory practice within prohibition of the Packers and Stockyards Act). Nevertheless, this similarity to conversion-exempt public utilities need not protect commission merchants. See note 5 supra.

17. See 244 F.2d at 631, citing Birmingham v. Rice Bros., 238 Iowa 410, 417-18, 26 N.W.2d 39, 43, cert. denied, 332 U.S. 768 (1947) : "Certainly, Congress did not adopt the Packers and Stockyards Act to encourage and protect the operation of fences for handling property stolen or procured by fraud. ... It is not wrongful discrimination to refuse to aid a criminal in his crime, nor is a request that one dispose of property fraudulently procured or stolen a reasonable request." See also De Vries v. Sig Ellingson \& $C_{0}$., 100 F. Supp. 781, 786 (D. Minn. 1951), aff'd, 199 F.2d 677 (8th Cir. 1952), cert. denied, 344 U.S. 934 (1953) ( $\$ 205$ of the Packers and Stockyards Act held not to require market agency to furnish services under any and all circumstances to any and all customers). 
Nevertheless, the common-law immunity of carriers might have been extended to auctioneers. ${ }^{18}$ Compelled to receive and forward all goods properly prepared for shipment in the usual course of business, ${ }^{10}$ a carrier is not liable to the true owner for innocently transporting goods at the direction of an unauthorized apparent owner. ${ }^{20}$ This protection, derived from the carrier's status as bailee, ${ }^{21}$ has been rationalized on grounds of commercial expediency. Although the carrier could investigate title before accepting goods from a prospective bailor, ${ }^{22}$ such inquiry is impractical. As a public intermediary dealing with transient chattels, the common carrier faces disproportionate delays in searching title. ${ }^{23}$ Limited liability renders inquiry and attendant disruption of commerce unnecessary. An auctioneer, while transferring title to goods, confronts similar delays if he seeks protection through investigation of ownership. ${ }^{24}$ And he is subject to comparable public utility restrictions. ${ }^{25}$ To the

18. Nanson v. Jacob, 93 Mo. 331, 6 S.W. 246 (1887). See Blackwell v. Laird, 236 Mo. A.pp. 1217, 163 S.W.2d 91 (1942) (strongly implying the analogy between carriers and commission agents). See note 5 supra. Notes, 33 TeXas L. Rev. 534 (1955), 32 Minn. L. Rev. 86, 89 (1947).

19. See Swayne \& Hoyt v. Everett, 255 Fed. 71 (9th Cir. 1919); Elliotr, BaIlliENts and Carriers $\$ \S 130,139$ (2d ed. 1929); 1 MichIE, Carriers $\$ 333$ (1915).

20. Shellnut v. Central of Ga. Ry., 131 Ga. 404, 62 S.E. 294 (1908) ; Nanson v. Jacob, 93 Mo. 331, 6 S.W. 246 (1887) ; Switzler v. Northern Pac. Ry., 45 Wash. 221, 8s Pac. 137 (1907); 1 Harper \& James, Torts $\$ 2.20$ (1956); 2 Restatement, Agency $\$ 349$, comment $d$ (1933). A carrier's immunity from conversion liability is atypical. At common law, a carrier is an insurer against loss or damage to goods received for carriage. Other exceptions arise only from acts of God or public enemies, the negligence of the shipper or the inherent nature of the property. 2 Wraran, Public SERVICE CoRporations $\$ \$ 984-91$ (1911) ; Note, Limitations on Liability for Negligence in Documents of Title, 32 NEB. L. Rev. 600, 601-02 (1953) ; 8 ALA. L. REv. 423, 424 (1955). Thus, the immunity is limited: a carrier who misdelivers goods is ordinarily liable in conversion to the shipper or person entitled to their possession unless misconduct (on their part) induced the error. See Estherville Produce Co. v. Chicago, R.I. \& Pac. R.R., 57 F.2d 50 (8th Cir. 1932) ; Maryland Lumber Co. v. White, 205 Md. 180, 107 A.2d 73 (1954).

21. In Birmingham v. Rice Bros., 238 Iowa 410, 420, 26 N.W.2d 39, 44, cert. denicd, 332 U.S. 768 (1947), the carrier's protection was distinguished on the ground that "the carrier in transporting does not undertake to deal with or affect in any manner the rights or title of the owners or chattel mortgagees in the shipments." This analysis was criticized in 32 MINN. L. REv. 86, 89 (1947).

22. A common carrier has the right to protect itself against fraud or imposition through reasonable and necessary rules for the transaction of its business. Cf. Henderson Coal Co. v. Public Serv. Comm'n, 73 Pa. Super. 45, 51 (1919) (dictum); Texas \& Pac. Ry. v. United States, 289 U.S. 627 (1933). Inspection of a shipper's title, apparently not involving unjust discrimination, would seem to be within this general rule.

23. See Note, 33 Texas L. REv. 534 (1955), which justifies exemption of the carrier on commerce-disruption grounds and analogizes the carrier and livestock commission agent.

24. See Citizens State Bank v. Farmers Union Livestock Cooperative Co, 165 Kan. 96, 113-14, 193 P.2d 636, 647-48 (1948) (dissent): "[M]arketing operations at the great livestock markets are of necessity ... integrated and fast-moving transactions . . . The required acceptance of consignments of livestock often crowding the market and demanding expeditious handling, permits no substantial delay if the service of bringing buyer and seller together is to be well performed. What sort of inquiries must it make in order to escape liability to some unknown mortgagee? How wide a territory must it include in the 
extent commercial considerations govern, denying him insulation allowed the carrier seems inconsistent. Moreover, investigation by the auctioneer would impede the aim of the Packers and Stockyards Act-an unhampered flow of livestock from range to stockyard. ${ }^{26}$

But strict liability does not in fact induce the auctioneer to investigate and hence does not cause commerce-disrupting delays. An auctioneer cannot afford delays and will, in the first instance, assume the risk of loss. ${ }^{27} \mathrm{He}$ may, of course, attempt to minimize this loss through increased commission fees within the rate structure fixed by the Secretary of Agriculture, and through insurance. ${ }^{28}$ Still, complete ability to shift risks is unlikely. ${ }^{29}$ The decisive ques-

scope of its delaying inquiries? . . . [T] tions of the regulated markets is a grave one, tending to delay and impede the service they are instituted to perform."

25. See note 16 supra. The Supreme Court, in Stafford v. Wallace, 258 U.S. 495 (1922), characterized stockyards as businesses affected with a public use, of a national nature and subject to national regulation. See also Packers and Stockyards Act, 42 StAT. 159 (1921), as amended, 7 U.S.C. \$\$ 181-231 (1952).

26. See Stafford v. Wallace, supra note 25; Birmingham v. Rice Bros., 238 Iowa 410, 424, 26 N.W.2d 39, 46, cert. denied, 332 U.S. 768 (1947) (dissent) ; H.R. REP. No. 77, 67th Cong., 1st Sess. 13, 14 (1921) ; 47 Colum. L. Rev. 861, 862 (1947).

27. A typical risk, borne by the transfer agent or bank, occurs when a legitimate order instrument is stolen, and payment is made on the forged endorsement. Cf. Union Bank \& Trust Co. v. Security-First Nat'1 Bank, 8 Cal. 2d 303, 65 P.2d 355 (1937). Yet banks tend to prefer faster service and increased risk as opposed to delays caused by preventive techniques. See 14 U. CHr. L. Rev. 705, 708 (1947). See also Corker, Risk of Loss From Forged Instruments, 4 STAN. L. Rev. 24, 30-31 (1951) ; Kessler, Forged Indorsements, 47 YALE L.J. 863, 896 (1938). If an auctioneer wishes to facilitate market operations, his need for fast service is no less urgent. See 33 Texas L. Rev. 534 (1955).

28. The Secretary of Agriculture has power to review rates submitted by stockyards covered by the act. 42 STAт. 164 (1921), 7 U.S.C. $\$ \$ 206,207$ (1952). Commission fees are determined with reference to a variety of factors, among which risk may be explicitly included. American Comm'n Co. v. United States, 11 F. Supp. 965, 970 (D. Colo. 1935). See note 36 infra.

Insurance for the auctioneer would appear no different in operation from insurance carried by brokers and banks against forgery losses. Such forgery insurance is not uncommon. See Notes, 14 U. CHI. L. Rev. 705, 709 (1947), 7 U. Chr. L. Rev. 497, 510 (1940). A market agency can also protect itself by requiring consignors of livestock to furnish a bond or insurance against loss. De Vries v. Sig Ellingson \& Co., 100 F. Supp. 781, 787 (D. Minn. 1951), aff'd, 199 F.2d 677 (8th Cir. 1952), cert. denied, 344 U.S. 934 (1953).

Conceivably, an auctioneer could demand a bond in every transaction, thereby avoiding the burden of title losses. But a bonding system is open to criticism, particularly when the true owner is a mortgagee. First, the mortgagee is better able to prevent losses than the professional bondsman, initially by lending money carefully and then by policing potentially fraudulent mortgagors. Cf. Gilmore \& Axelrod, Chattel Security: $I, 57$ YaLE L.J. 517,538 (1948). Second, if the bondsman conducts a title investigation, he faces the same delays as the auctioneer. Finally, compared to a mortgagee, a bondsman is not a significantly superior distributor of risks. A mortgagee shifts losses to mortgagors in the form of higher interest rates while a bondsman shifts losses to consignors through higher bonding charges. Thus, both are professional, compensated risk bearers. See note 44 infra and accompanying text.

29. Rate increases must meet with the Secretary of Agriculture's approval. See note 
tion, then, is which of two innocent parties shall bear the loss created by the consignor: the auctioneer or the true owner. ${ }^{30}$ Ideally, the solution should depend on the comparative ability of each to spread risk and prevent loss. ${ }^{31}$

When unmortgaged goods are stolen or obtained by fraud, auctioneer and rightful owner are equally capable of preventing loss, but the auctioneer is better able to spread risk. Placing liability on the owner prevents loss by im-

28 supra. And administrative regulation may make it difficult for an agent to spread the risk of loss through increased fees. 47 CoLum. L. REv. 861, S62-63 (1947). See also Sellers, Procedures of Regulatory Agencies in the United States Department of Agriculture, 25 WASH. U.L.Q. 352, 370 (1940). Determined as a percentage of capital investment, fees have approximated seven per cent. Denver Union Stock Yard Co. v. United States, 21 F. Supp. 83, 91. (D. Colo. 1937), aff'd, 304 U.S. 470, 485 (1938). Even increased rates will not shift the entire cost of risk, since under competitive conditions a market agency's business volume may decline as charges rise. See Note, 66 Y AlE L.J. 1107, 1119 n.62 (1957).

30. This dichotomy assumes that the consignor is either insolvent or unavailable and that the purchaser from the auctioneer is also unavailable or protected by a factors' act. See note 9 supra. Theoretically, since the true owner has full title to the chattel, he can proceed at his option against either the misappropriating consignor, the innocent auctioneer or the purchaser from the auctioneer. Comment, Conversion by Imnocent Agents, 28 YaLE L.J. 175, 177 (1918); note 9 supra. Usually, however, the problem becomes one of placing the burden of loss on the true owner or the auctioneer, both of whom are likely to be free from fault. See note 31 infra.

31. On ability to spread risk, see, generally, James, Accident Liability Reconsidercd: The Impact of Liability Insurance, 57 YALE L.J. 549 (1948) ; Morris, Hazardous Enterprises and Risk Bearing Capacity, 61 YaLE L.J. 1172 (1952); Douglas, Vicarious Liability and Administration of Risk, 38 Y ALE L.J. 584, 720 (1929) ; Comment, Allocation of Losses From Check Forgeries Under the Laze of Negotiable Instruments and the Uniform Conmercial Code, 62 YalE' L.J. 417, 433 (1953); Note, Forged Government Checks: Misallocation of Loss by the Federal Common Law, 66 YALE L.J. 1107 (1957). See also Willett, The Economic Theory of Risk and Insurance 101-02 (1951): "There are two ways in which society may reduce the cost of uncertainty. It may adopt means to prevent the occurrence of . . loss, or measures which will reduce the degree of uncertainty ... without affecting the amount of positive loss. All measures of the former kind may be grouped under the name of prevention. ... The general method of reducing uncertainty ... is through transfer of risk."

The negligence concept is the primary judicial device for allocation of liability where the parties are in a position to prevent potential loss. True, a judicial standard based on negligence comprises only one factor inducing careful conduct. See James, supra at 557-58. Nevertheless, the negligence approach as a means of achieving loss prevention is not unrealistic. Comment, 62 Y ALE L.J. 417, 438 (1953). For applications of this notion, see Royal Indemnity Co. v. Federal Reserve Bank, 38 F. Supp. 621 (S.D. Ohio 1939), aff'd per curiam, 119 F.2d 778 (6th Cir. 1941) (where third person's fraud results in loss, party who first reposed confidence and committed the first oversight must bear loss); Keck v. Browne, $314 \mathrm{Ky} .151,234$ S.W.2d 183 (1950) (as between cashing bank and drawer, drawer bears loss where his own conduct invited the forgery).

If neither party is able to prevent loss, however, it should be allocated to the better risk distributor. Conversely, risk-spreading facilities being equal, prevention or "moral" negligence principles may again take precedence. See Note, 8 U. CHI. L. REv. 729, 743-45 (1940). 
pelling him to act prudently. ${ }^{32}$ Similarly, auctioneer liability, which in practice fails to avert loss by forcing careful examination of title, precludes use of immunity as a shield for sales of goods known to be illegally procured. ${ }^{33}$ The auctioneer, however, is generally better able than the owner to distribute the cost of losses from theft and fraud as business expenses. ${ }^{34}$ If legislative regulation and difficulty of obtaining insurance make the auctioneer less than a perfect risk spreader, the true owner's normally noninstitutional character renders him an even less likely insurer and risk distributor..$^{35}$ Moreover, under the Packers and Stockyards Act, the government can make risk a cost item in rate schedules. $^{36}$ If this cost consists merely of premiums paid an insurance company for

32. Hence, a cattle owner, knowing that he must bear the burden of potential loss in case of theft or fraud, will presumably deal with strangers more carefully and, at the same time, take every precaution against theft. This reasoning, though attractive, is somewhat deceptive. For fear of legal liability is not the sole inducement to careful conduct but merely one of a constellation of motivations. See James, supra note 31, at 557-59.

33. An early argument against granting immunity to innocent auctioneers or market agencies was that to do so would foster the sale of stolen goods. Hence, in Hoffman v. Carow, 22 Wend. 285, 319-20 (N.Y. 1839), Senator Verplanck urged: "I cannot conceive a more salutary regulation than that of obliging the auctioneer to look well to the title of the goods which he sells, and in case of feloniously obtained property, to hold him responsible to the buyer or the true owner, as the one or the other may happen to suffer. Were our law otherwise in this respect, it would afford a facility for the sale of stolen or feloniously obtained goods, which could be remedied in no way so effectually as by a statute regulating sales at auction."

34. The institutional enterprise can calculate the incidence of loss and offset it through higher rates or through insurance. Otherwise, the loss falls sporadically and unaccountably on individuals, who often have no means of protection against it. See Corker, supra note 27 , at 31 : "If banks assume the risk of loss by forgery, the cost will ultimately be passed on to all their depositors. If depositors bear the risks, losses will fall at random with the impact of unpredictable disaster." As an institutionalized if nonnegligent agent, therefore, the auctioneer is in a better position both to predict and distribute loss than the individual true owner. See Kessler, supra note 27, at 896-97; Comment, 43 ILL. L. REv. 823, 831 (1949); Note, 37 Minn. L. Rev. 201, 204 (1953). See also Note, 8 U. Chr. L. Rev. 729, 743-45 (1941).

35. For cases in which the rightful owner is noninstitutional, see, e.g., John Clay \& Co. Livestock Comm'n v. Clements, 214 F.2d 803 (5th Cir. 1954) (individual cattle dealer defrauded) ; Blackwell v. Laird, 236 Mo. App. 1217, 163 S.W.2d 91 (1942) (cattle stolen from individual owner); Walker v. Caviness, 256 S.W.2d 880 (Tex. Civ. App. 1953) (same) ; Cresswell v. Leftridge, 194 S.W.2d 48 (Mo. Ct. App. 1946) (individual cattle owner defrauded); Moderie v. Schmidt, 6 Wash. 2d 592, 108 P.2d 331 (1940) (same). See Morris, supra note 31 , at 1177 , which contrasts the institutional enterpriser with calculable risks and the noninstitutional injured party by whom certain classes of risk are unforeseeable. The enterpriser, by this analysis, is a better distributor of risk.

36. 42 STAT. 166 (1921), as amended, 7 U.S.C. $\$ 211$. (1952), provides that the Secretary of Agriculture "may determine and prescribe what will be the just and reasonable rate or charge ... and what regulation or practice is or will be just, reasonable and nondiscriminatory." In determining reasonable rates, the Secretary can use as a basis: property value including land, labor, construction overhead, interest on used and useful land and working capital. Denver Stock Yard Co. v. United States, 304 U.S. 470, 478 (1937). But rates can also be gauged to include agency selling costs. Among such costs 
indemnity against loss, computation and inclusion of cost are simple matters. When insurance is unavailable, computation becomes more difficult. Still, the cost of losses could be determined on a long-term empirical basis and be given ultimate recognition under the act. ${ }^{37}$ Alternatively, the government could make insurance available, thus facilitating both computation of cost and risk spreading. ${ }^{38}$

When loss is caused by a fraudulent mortgagor as in Matthews, recordation requirements do not increase the auctioneer's capacity for loss prevention, and cost is better distributed by the mortgagee. In theory, recordation avails the auctioneer of a sufficient opportunity to prevent passage of defective titles. ${ }^{30}$ And, if he does business in the state or county of recordation, recourse to mortgage files may in fact yield notice. More often, however, title search is commercially unfeasible and will not reveal liens on rapidly moving chattels. ${ }^{40}$ These shortcomings are most evident when the auctioneer conducts his busi-

is risk. Hence, in American Comm'n Co. v. United States, 11 F. Supp. 965, 969-70 (D. Colo. 1935), the court said that charges should be "no more than the reasonable cost of seiling a carload of cattle. This to be arrived at by taking the cost of performing the necessary services .... This he did by finding the aggregate cost of handling the cattle .... the number of men reasonably necessary to perform the services, the amount of salaries necessary to pay them, making reasonable allowance for all other proper costs, including management risk ...." Later in the opinion, the court added that risk compensation, having been allowed in the category of risk expense and profit, should not have been included as a selling cost. Id. at 970 . But cf. United States v. Morgan, 313 U.S. 409 (1940) (Secretary of Agriculture's function in determining rates for services rendered not merely to examine expenditures and actual income but to inquire whether services are properly chargeable to the public).

37. Retrospective empirical data have been authorized in rate-making generally. In gathering evidence concerning rates, the Secretary has been held entitled to examine conditions over such a period of past operations as would enable him to make a fair prediction in fixing maximum rates. See St. Josephs Stock Yards v. United States, 298 U.S. 38, 46-47 (1936).

38. The Federal Deposit Insurance Corporation, for instance, is an adjunct to a federal banking and currency system. See Hust, Federal Deposit Insurance and Some of Its Constitutional Aspects, 7 GEo. WAst. L. Rev. 595, 628-29 (1939). Similarly, government insurance held by market agencies subject to the Packers and Stockyards Act could be considered supplemental to that legislation.

39. See Mason City Production Credit Ass'n v. Sig Ellingson \& Co., 205 Minn. 537, 286 N.W. 713, cert. denied, 308 U.S. 599 (1939) (livestock chattel mortgage filed in Iowi constructive notice under Iowa law to Minnesota market agency registered under the Packers and Stockyards Act). But constructive notice of a recorded chattel mortgage may be specifically inapplicable to an agent not asserting a property interest in the goods. Greer v. Newland, 70 Kan. 315,78 Pac. 835 (1904) ; First Nat'l Bank v. Siman, 65 S.D. 514,275 N.W. 347 (1937) (dictum). If classed as a subsequent purchaser, however, the auctioneer must search the public records to protect himself. See Comment, 35 Texas L. Rev. 246, 248 (1956).

40. See Note, Effect of Sale by Mortgagor of Chattels Subject to Mortgagc, 46 YaLE L.J. 1090, 1092-93 (1937); Legis., The Uniform Chattel Mortgagc Act, 19 VA. L. Rev. 635 (1933) ; Myerson, Practical Aspects of Some Legal Problems of Sales Finance Companies, 2 LAw \& Contemr. ProB. 244, 250-51 (1935). 
ness outside the jurisdiction of recordation. Foreign recording is regularly recognized when the chattel is removed without notice to the mortgagee. ${ }^{41}$ Such extraterritorial operation heightens the auctioneer's difficulties in obtaining actual notice. Accordingly, he has no greater ability to prevent losses occasioned by fraudulent mortgagors than those attributable to theft or fraud in the absence of a mortgage. ${ }^{42}$ The mortgagee, on the other hand, is better able to distribute

41. See Mercantile Acceptance Co. v. Frank, 203 Cal. 483, 265 Pac. 190 (1928) ; General Motors Acceptance Corp. v. Nuss, 195 La. 210, 196 So. 323 (1940); 2 Beale, CoNFLICT OF LAWS $\$ \$ 268.1,275.1$ (1935) ; RestaTEMENT, Conflict of LAws $\$ 268(1)$ (1934); 29 Ned. L. Rev. 124 (1949). But see id. at 126; Farmer v. Evans, 111 Tex. 283, 233 S.W. 101 (1921) (minority view).

42. A system of mortgage registration might be devised, however, which would allow auctioneers to check title and thus justify imposition of liability on loss-prevention grounds. Conceivably, such a system might be developed in the form of a federal clearinghouse, not dissimilar to motor vehicle registries. Perhaps most troublesome of all transient chattels, automobiles have called forth various antitheft devices to protect both moneylender and ultimate purchaser. The certificate of title, for instance, has often been linked with central filing of liens by a commissioner of motor vehicles. Leary, Horse and Buggy Lien Lazw and Migratory Automobiles, 96 U. PA. L. Rev. 455, 460 n.12 (1948) (collecting state statutes with central filing provisions). Both the methods and objectives of central filing for automobile liens are adaptable to livestock chattel mortgage situations, with the added advantage that no problem of reregistration in another state through a forged bill of sale would be presented. For a discussion of the reregistration problem, see id. at 460 .

Nevertheless, a difficulty does arise concerning the scope of effect that central filing should have. If central filing is a substitute for ordinary recordation only upon removal of the chattel to another state, it would appear to be clearly within the commerce power. Central registration pre-empting regular notice on intrastate chattels, however, might be considered a federal encroachment on state powers. Militating against such an interpretation of potential clearinghouse legislation is the specifically interstate character of stockyards and market agencies. See Stafford v. Wallace, 258 U.S. 495 (1922). Ideally, a mortgagee wishing to protect his security interest in livestock would be obligated to record at a regional filing bureau whether or not the livestock was intended for interstate commerce. A prudent mortgagee would record centrally in any event, to guard against the possibility of loss through fraudulent removal to another state. Should the clearinghouse employ modern automated techniques in filing and reporting liens, inquiry by telephone or telegraph, which should not slow commercial transactions appreciably, might be possible. See Van Deusen, The Coming Victory Over Paper, Fortune, Oct. 1955, pp. 130, 132: "What the banking profession has needed is a machine that will rapidly handle paper checks of varied size and at the same time automatically extract enough information from each check so that data may be manipulated ... without further reference to the check itself. This, essentially, is what Bank of America's machine does, using magnetic markings on the back of the check as a source of information. And the Bank of America machine is a forerunner of a whole series of similar new devices and systems . ..." Proper application of such methods to a mortgage clearinghouse might make time a negligible factor in conducting title searches.

The cost of such a system would, of course, fall on the mortgagee, the best available risk distributor. See notes 43,44 infra and accompanying text. A similar marginal cost problem is encountered by banks in regard to stop-payment orders on checks, the cost of which includes both the value of resources expended in the mechanics of stopping checks and the actuarial cost of payment without recourse. A tendency toward equilibrium is inherent in the stop-payment operation if the bank bears the burden of erroneous payment. 
loss than the rightful owner of unmortgaged goods or the auctioneer. ${ }^{43}$ Generally at least as institutionalized as the auctioneer, the mortgagee is in the business of lending money at a rate of interest reflecting estimated risk of loss. ${ }^{44} \mathrm{He}$ is, therefore, an almost ideal risk spreader. Especially is this true in cases arising under federal law, which normally applies only when the government, the optimum risk-spreading organization, is mortgagee. ${ }^{4 \pi}$

When fraud or theft colors a sale of livestock, courts should gear liability to the relative capacity of the parties for risk distribution. Absent notice, the auctioneer is as innocent as the mortgagee or rightful owner. ${ }^{46}$ Each has comparable ability to prevent loss. ${ }^{47}$ They differ, however, in capacity to distribute risk. So viewed, liability should rest on the auctioneer in cases involving unmortgaged goods and on the mortgagee when the livestock has been mortgaged. ${ }^{48}$ To reach this result, courts will have to interpret recording statutes to give constructive notice only to subsequent purchasers, encumbrancers and mortgagees, and not to auctioneers without a property interest in the chattels..$^{49}$

It will then incur costs in the attempt to stop payment up to the point where marginal costs are equal in amount to the attributable reduction of risk. Comment, Stop Payment: An Ailing Service to the Business Community, 20 U. CHI. L. REv. 667, 669 (1953) ; cf. Note, 66 YALE L.J. 1.107, 1117 n.52 (1957). This marginal cost analysis is equally applicable to livestock mortgagees who would pay for the privilege of central recording. In fact, strict application of the analysis would require mortgagees to bear telegraph and telephone charges incurred in checking title.

43. See Note, 46 Yale L.J. 1090, 1093 (1937). See also Gilmore \& Axelrod, supra note 28, at 517 n.1: "The focus of security law is not, and ought not to be on the protection of the lender against the borrower's 'fraud'; the 'fraud' situation itself is likely to be an aspect of debtor behavior on threatening insolvency, or else is too infrequent to be worth bothering about outside the criminal law."

44. See Murrax, Agricultural Finance 112 (1946) : "Risk is another factor that affects the interest rate. Lenders, as a rule, compete actively for large loans in low risk territory. High risk areas ... are avoided by the lending agencies who are looking for relatively safe loans. These agencies are willing to lend on farm mortgages at $4 \%$ in the Corn Belt rather than ... at $6 \%$ in the drouth [sic] sections of the Great Plains." The local moneylender may be an especially good bearer of risk for other reasons. He usually has a thorough knowledge of his customers that is distinctly helpful in short-term lending, and his interest rates are often fixed and noncompetitive, yielding a higher than normal profit. See $i d$. at 169,172 (local commercial banks).

45. See Note, $66 \mathrm{Y}_{\text {ALE }}$ L.J. 1107,1118 (1957), which emphasizes the unique pusition of the government as risk distributor.

According to the Clearfield doctrine, federal law applies whenever the government sues on paper it has issued. See note 13 supra. Thus, government mortgage paper requires the use of federal law. If the government sues after goods have been stolen from it or otherwise fraudulently obtained, however, government paper would probably not he the basis of the suit, and Clearfield would not control.

46. See note 15 supra and accompanying text.

47. See notes 32,33 supra and accompanying text. The mortgagee's capacity to select borrowers carefully may be considered to put him in a good position to prevent loss. See note 44 supra. Such an argument, however, seems better suited to rationalize than to create his liability. See text at note $\mathbf{5 0}$ infra.

48. See text at notes $34,35,44,45$ supra.

49. See note 39 supra. 
IVithin this framework, technical grounds can be employed to shift liability between the mortgagee and the auctioneer. When the livestock is unmortgaged, the auctioneer can be deemed a converter as he is under existing law. When a mortgage is involved, the auctioneer's liability as a converter can be considered overcome by the mortgagee's act of putting the mortgagor in a position to create the loss. ${ }^{50}$ Once choosing to deal with the mortgagor, the mortgagee must undertake the attendant credit risks. ${ }^{51}$ Utilization of these technical grounds will enable courts to recognize commercial reality in determining liability for business conversion.

50. Some courts have held that the mortgagee initiates the causal chain culminating in the loss by clothing the fraudulent mortgagor with apparent ownership. See Consolidated Garage Co. v. Chambers, 111 Tex. 293, 231 S.W. 1072 (1921) (overruled by Bank of Atlanta v. Fretz, 148 Tex. 551, 226 S.W.2d 843 (1950)) ; 14 U. CHr. L. Rev. 713, 717-18 (1947). This reasoning is merely a specific application of the general equitable principle that where one of two innocent persons must suffer a loss, it should be borne by the one who has rendered the loss possible. National Safe Deposit Co. v. Hibbs, 229 U.S. 391 (1913) (when bank as assignee of blank stock certificates entrusts them to clerk who sells them to innocent stockbroker, bank must answer for the loss); Schrader v. Westport Ave. Bank, 236 Mo. App. 362, 156 S.W.2d 753 (1941) (when stockbroker fraudulently pledges securities belonging to customer, pledgee can retain securities until repaid amount due him).

51. See note 50 supra. See also Report of the Commissioners on a Uniform Chattel Mortgage Act, in Handbook of the National Conference of Commissioners on UNIFoRA STATE Laws 417 (1926): "[T] he draft proceeds on the basis that the mortgagor's honesty is a credit risk which is undertaken by the mortgagee." 